Center for

Mathematical Economics

Working Papers

December 2014

\title{
Credit Constrained R\&D Spending and Technological Change
}

Pascal Aßmuth

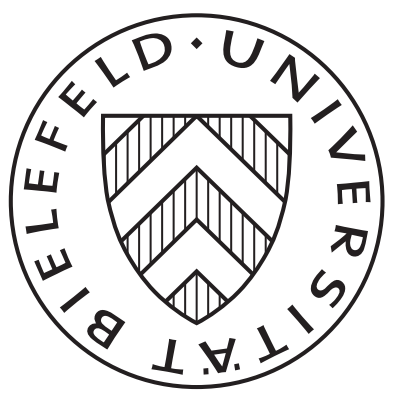




\title{
Credit Constrained R\&D Spending and Technological Change
}

\author{
Pascal Aßmuth*
}

December, 2014

\begin{abstract}
Firms often rely on external financing in order to conduct $R \& D$. The question is to what extent discriminatory behaviour of the funds provider affects the industry evolution. The model is based on an evolutionary framework by Nelson and Winter. A firm chooses its $R \& D$ spending in an adaptive fashion where technological improvement is essential for survival in the competitive market. Firms can finance their activities by using retained profits or applying for credit. However, they have a clear hierarchy in choosing the source of funds and saved profits are always used up first. There is endogenous discriminatory lending as the banking sector provides credit according to firms' individual features. It compares profitability and market share across firms when assessing creditworthiness. The model is able to capture features of innovation and diffusion of technology. Results show that the availability of credit is crucial for technological change in a non-linear fashion and that the industry evolves faster if the bank values market share more in assessing creditworthiness.
\end{abstract}

Keywords: Heterogeneous Agents Models, Innovation, Financial Constraints JEL-Classification: D92, G32, O33, O41

\footnotetext{
* Bielefeld Graduate School of Economics and Management (BiGSEM), Center for Mathematical Economics, Bielefeld University, and Université Paris I Panthéon-Sorbonne, C.E.S.

pascal. assmuth@uni-bielefeld.de

This work was carried out within International Research Training Group EBIM (Economic Behavior and Interaction Models) financed by the DFG under contract GRK 1134/2.

I would like to thank Herbert Dawid and the participants of the EDEEM Workshop 2013 in Louvain-La-Neuve for very useful comments and remarks.
} 


\section{Introduction}

Empirical research shows that $R \& D$ spending is affected by constraints in external funding. The effect is attributed to fluctuations in $R \& D$ spending that are accounted for by restrictions in credit markets or access to equity, for example due to lack of financial institutions. ${ }^{1}$ Another explanation is higher costs of external capital whose impact is identified in Dutch samples, ${ }^{2}$ Italian manufacturing samples ${ }^{3}$, French manufacturing firms, ${ }^{4}$ and US vs. European samples. 5 Explanations are based on the information shortage of external financiers compared to the researcher. This disadvantage leads credit or equity providers to require a higher risk premium. Furthermore, even if R\&D produces some innovation that can be implemented, this measure does not yield tangible assets that can serve as collateral for a loan. This also contributes to the risk premium. ${ }^{6}$ This view is supported by evidence that considers sub samples of firms that are more likely to be constrained, namely small and medium enterprises and young firms. Because those lack either collateral and/or a proven history of creditworthiness, their ability to pay back a loan is highly uncertain. This finding is supported by an analysis of Brown et al. (2009) who find that an improved supply of equity can trigger an R\&D boom because relatively young firms benefit from that. Consequently, a lack of that supply also can lead to a bust in R\&D activity as the R\&D cycle in the U.S. in the 1990 s showed. ${ }^{7}$ Moreover, firms that have a high R\&D intensity suffer comparatively more from constraints because they usually require relatively higher external funding. ${ }^{8}$ Therefore, firms that show inherently one or more of the adverse features suffer discrimination in access to credit. ${ }^{9}$ The particular role of uncertainty of creditworthiness is pointed out as is shown for Finland. ${ }^{10}$ In this case public subsidies can have a positive effect because they not only allow a research project to take place but also increase the trust in creditworthiness by others and thus may enable external financing in the future. ${ }^{11}$

The aim of this paper is to assess the impact of the described effects in a world where the acting entities react to each other. That is, how much the industry, the R\&D undertaken, and the innovation success change if credit restrictions change. More precisely, the impact of changes in behaviour is accounted for to understand why credit shortages have the observed impact. For instance, there might be little demand for credit in general and in this case shortages do not matter. Or there can be a mismatch between those entities that demand credit

\footnotetext{
${ }^{1}$ Among others, see Hyykinen and Toivanen (2003).

${ }^{2}$ Mohnen et al.(2008).

${ }^{3}$ Mancusi and Vezzuli (2010).

${ }^{4}$ Savignac (2007).

${ }^{5}$ Ravera and Canet (2001).

${ }^{6}$ Among others, see Mohnen et al. (2008), Czarniki and Hottenrott (2011) for an overview.

${ }^{7}$ See Brown et al. (2009), p. 152.

${ }^{8}$ Piga and Atzeni (2007).

${ }^{9}$ Canepa and Stoneman (2008), Hao and Jaffe (1993), Giudici and Pateari (2000), among others.

${ }^{10}$ Hyykinen and Toivanen (2003)

${ }^{11}$ Takalo and Tanayama (2010).
} 
and those that would have access. This imbalance then determines how an increased supply of credit affects the various $R \& D$ efforts.

The model is set in a dynamic agent based framework building on the work of Nelson and Winter $(1982,1984)$ which is set in an evolutionary environment under Schumpeterian competition. ${ }^{12}$ In each period the bank uses information about the firms in order to determine how much credit it would be willing to lend to each of them. It has a particular routine of doing so by relying on the assessment of creditworthiness based on multiple features. At the same time, each firm produces and conducts $R \& D$ to some extent. The outcome is some quantity of a homogenous good which jointly with all other firms determines the market price and automatically the profit of each firm on the one hand. On the other hand the R\&D effort might lead to the finding of a better technology which the successful firm can use in the production process of the next period. This leads the successful firm to wanting to invest more for the next round of production. However, this possibility depends on the current profit and available credit. If the firm can exploit that technological improvement it will have better access to credit in the next period. There are two feedback effects employed in the model: a better technology improves access to credit and access to credit improves the probability of finding a better technology. Both effects are however, subject to individual behaviour of both, the bank and the firms. Thus, the effectiveness of the feedback varies in the behavioural routine of the agents.

Results show that an increase of credit supply translates non-linearly to changes in output and industry concentration. More credit always is contributing to more innovation, faster growing output and a faster concentrating economy. Nevertheless, if there is either too tight credit or plenty of credit, increasing credit supply has only a very meager effect. There is a threshold of credit supply below which the industry evolves more slowly and above which it evolves with a much higher pace. When the bank determines credit supply by comparing firms by profitability and by market share the industry grows faster when the focus is on market share. The reason is that firms' innovation success is more directly observable in market share while the increase in profitability depends on its access to credit. Therefore, innovative success is more persistent if the bank offers credit mainly on the market share. Furthermore, firms can influence their R\&D success by adapting their effort only if there is much credit available.

This paper strengthens the role of information shortages of lenders as explanation for R\&D spending patterns. Since the banking sector bases its decision on two observable firm features but does not have any information about the technology that will be applied in the upcoming production period, it can happen that even innovative firms face credit shortages.

The remainder of the paper is organized as follows: section 2 gives an overview about the relationship between credit constraints and $R \& D$ funding. Section 3 introduces the model and the experiments. It also discusses results while section 4 makes conclusive remarks.

\footnotetext{
${ }^{12}$ Nelson and Winter (1982) and Winter (1984).
} 


\section{Credit Constraints and R\&D Effort}

According to empirical literature, constraints in external funding affect R\&D efforts of firms. ${ }^{13}$ Hall and Lerner give an overview of the way R\&D and innovation are funded. Small and new innovative firms experience high costs of capital, the evidence for large firms is mixed. Large firms prefer internal funding and manage their cash-flow accordingly. ${ }^{14}$ There is evidence that firms are constrained in financing $R \& D$ for several reasons. Concerning credit a major aspect is the insecure outcome of $R \& D$ in conjunction with relatively high monitoring costs. Therefore, firms might not be able to be granted credit to the amount they would like to. ${ }^{15}$ For a United Kingdom data-based empirical study, Freel finds that small firms that are innovative actually experience less credit granting success than their less innovative competitors. ${ }^{16}$ Supportive findings for high-tech firms are provided by Guiso who uses Italian samples. Cross-sectional data shows that manufacturers in high-tech categories have a higher probability of being constrained in credit. ${ }^{17}$ The predominant reason might be that there is higher uncertainty related to producing at the edge of technology.

\subsection{Assessing Creditworthiness}

The process of granting a credit involves the assessment of many pieces of information. The creditor needs to know how likely it is that his loan is paid back. The evaluation usually takes place in form of a credit rating which includes not only hard figures but also more soft information about the debtor, first of all his relation to the creditor and their commercial history. Banks use ratings that are to some extent standardized. The customer adviser rates each of the categories according to some guidelines, but under her own discretion. For instance, the German credit unions (Volks- und Raiffeisenbanken) used the - in the meanwhile replaced -concept: management, market and sector, customer relation, economic situation of the customer, forecasted corporate development. All these factors receive a weight between $1 / 6$ and $1 / 4$. Then, summing up the assigned marks, the bank yields the rating. ${ }^{18}$ The instrument of rating is also necessary because it is required by the Basel agreement that banks hold equity according to the risk assessed credits they granted. ${ }^{19}$ Although the probability of default (of repayment) is the crucial figure to estimate, banks do rely mostly on heuristic methods to assess that probability, even if there are also statistical and causal analytical methods, like models of option pricing. One reason is that statistical methods are only meaningful if the

\footnotetext{
${ }^{13}$ Among other, e.g. Brown et al. (2009), Mohnen et al. (2008).

${ }^{14}$ Hall and Lerner (2009).

${ }^{15}$ See Freel (2007), p. 25.

${ }^{16}$ See Freel (2007), p. 32.

${ }^{17}$ See Guiso (1998), p. 55.

${ }^{18}$ Reichling et al. (2003), pp. 46-49.

${ }^{19}$ See Reichling et al. (2003), p. 39.
} 
data set is sufficiently large. ${ }^{20}$ This example of a rating model shows that the current economic situation of the customer plays the most crucial role, along with the customer history. The assessment of the future counts only as much as the management or the commercial sector does. Nevertheless, "[a]n assessment that only includes the present must not be decisive - the [firm's] focus on the orientation to the future must be satisfactory." 21

\subsection{Adaptive R\&D Strategies}

There is also some indication that R\&D policy and credit constraints are related. Aghion et al. $(2005,2012)$ find that credit rationing influences the R\&D policy of French firms where the effect depends on the degree to which firms are financed externally. ${ }^{22}$ The effects constraints have are less that projects are not carried out to the full extent but rather that they are not started at all. ${ }^{23}$ Furthermore, firms try to mitigate their dependence on outside funding by building up cash reserves which allows them to smoothen R\&D activity over time. This behaviour is encouraged by high adjustment costs because R\&D costs consist mainly of high wages for specialised researchers. ${ }^{24}$ Adaptive strategies due to learning outperform static rules for investment. ${ }^{25}$ Other insights about firms' R\&D strategies are:

- Ben-Zion 1984: Investment in R\&D is riskier than investment in production (expansion) since there is more uncertainty about the outcome of research. Therefore, since in good times investment in R\&D is easier to justify, research investment increases in economically favourable times.

- Yildizog/u 2002: Investment is not static. Learning makes a huge difference. Firms using adaptive research strategies perform better. Also, the higher the share of learning firms in an economy the further upward technology is pushed and so is output. Furthermore, firms who do not experience success of $R \& D$ after a while tend to abandon research activities. Also high competition among firms leads to lower R\&D.

- Lee and Harrison 2001: Depending on outside firm conditions it is possible to see firms using both, innovative and imitative strategies at the same time or that almost all firms (i.e. the vast majority) tend to either strategy. The important factors for this are the probabilities of payoffs, the distribution of payoff amounts and lag times for payoffs of an investment that had been made.

\footnotetext{
${ }^{20}$ Reichling et al. (2003) p. 55.

${ }^{21}$ Kremer and ten Hoevel (1989), p. 122.

${ }^{22}$ Aghion et al. (2005) and Aghion et al. (2012).

${ }^{23}$ Mancusi and Vezzuli (2010).

${ }^{24}$ Brown et al. (2012).

${ }^{25}$ Yildizoglu (2002).
} 
- Yildizoglu 2001: When discussing the particular way in which firms learn, not only adaptation is important, but also expectations. Expectations are usually overlooked in modeling learning processes.

Also, $R \& D$ investment is special because more than $50 \%$ of spending is due to high wages for knowledge workers. Therefore, "[f]irms tend to smoothen R\&D investment over time in order to avoid having to lay off knowledge workers." 26

Furthermore, Ben-Zion (1984) mentions the relation between (stock and bond) market value (and investor strategies) and the R\&D decisions of firms. Ben-Zion in the same paper also talks about the opposite direction which is the relation between $R \& D$ activities and stock market value: "[M]arket value of a firm is affected by its $R \& D$ and investment policy." 27 The main question for the R\&D policy is what can/do firms observe and in which direction do they alter their policy.

\section{The Model}

The model approach is about the evolution of an industrial sector where firms compete in improving their technology applied in the production process of a homogenous good. Demand is given and joint output determines the market price and implicitly each firm's profit. In order to improve their technology, firms rely on their retained profits and possibly on external sources of funds. In some situations there might be shortages in available funding. This model aims at the question which role the assessment of creditworthiness plays in the evolution of the sector in the presence of feedback mechanisms. Furthermore, the impact of the firm strategy of how to conduct $R \& D$ on the industrial output is examined. The time-line of events is as follows:

1. The bank has some amount of credit available for lending. According to the firms' features at the beginning of the period, it decides how much credit to grant each firm.

2. Firms have a size equal to their stock of physical capital $K_{i t}$. They produce output and simultaneously draw for better technology. Joint output determines the market price $P_{t}$. And the draw determines the available technology in the next period.

3. Firms observe their current profits and the success of their R\&D effort. Then, each firm decides about physical investment and R\&D spending. If desired total spending exceeds internal funds available, the firm applies for a credit.

\footnotetext{
${ }^{26}$ Hall and Lerner (2009), p.5.

${ }^{27}$ Ben-Zion (1984), p. 310.
} 
4. The credit offered and credit demand determine the funds available for a firm to invest in physical capital and to additionally perform R\&D. The impact of investment and R\&D is effective in the next period.

This is a model where the firms do not possess exclusive rights for their technology, like a patent. The effect of this (lack of) legal framework may indeed be that competition might lead to less $R \& D$, at least for innovative activities, since the incentives for cost reduction are lower. ${ }^{28}$ It has to be pointed out that innovation can take many forms, like product or process innovation where in this framework, only process innovation is replicated. The general difference is that product innovation is even less certain than process innovation, partly due to the more incremental character of process innovation. ${ }^{29}$ While innovation can also be distinguished by its effect of reducing production costs or increasing the output per unit of input, the following framework assumes that output increases, which is in line with Schumpeter's definition of innovation: "we ... define innovation as the setting up of a new production function." 30

\subsection{Setup}

Output $Q$ is generated by technology $A$ and capital $K$ by each firm at each period:

$$
Q_{i t}=A_{i t} K_{i t}
$$

Total output is equivalent to fixed demand so that the market price $P$ follows an inverse demand function

$$
\begin{aligned}
Q_{t} & =\sum Q_{i t}=\sum A_{i t} K_{i t} \equiv D_{t} \\
P_{t} & =\frac{D_{t}}{Q_{t}}
\end{aligned}
$$

\footnotetext{
${ }^{28}$ See Gilbert (2006), p 173.

${ }^{29}$ See Schumpeter $(1939,1942)$ for a detailed discussion of the degree to which new techniques trigger readjustments of or even setting up capital and processes.

${ }^{30}$ Schumpeter (1939), p. 83.
} 
In case of drawing an imitation the firm adopts the industry's best technology. If drawing an innovation, it gets a sample from a distribution of technical opportunities distributed according to

$$
F\left(\tilde{A}_{i t} ; A_{i t}\right)
$$

while $\tilde{A}_{i t} \sim \operatorname{LogNormal}\left(A_{i t}, 1\right)$. This implies that any innovation that is found is actually better than the currently employed technology. Successful draws are indicated by

$$
\chi_{i t}^{i m, i n}=\left\{\begin{array}{l}
1, \text { if there is a successful draw of imitation (im) or innovation (in), } \\
0, \text { else. }
\end{array}\right.
$$

For a firm the productivity level of following periods is given by

$$
A_{i(t+1)}=\operatorname{Max}\left(A_{i t}, \chi_{i t}^{i m} \hat{A}_{t}, \chi_{i t}^{i n} \tilde{A}_{i t}\right)
$$

Here $\hat{A}_{t}$ is the highest (best practice) productivity level in the industry in period $t$, and $\tilde{A}_{i t}$ is a random variable that is the result of the innovation draw. A firm's desired expansion or contraction is determined by the ratio of price to production cost $\frac{P \cdot A}{c}$ or, equivalently, the percentage margin over cost, and its market share. A firm's ability to finance its investment is constrained by its profitability, which is affected by its R\&D outlays as well as by revenues and production costs. Capital is subject to depreciation at rate $\delta$ and investment $I$. Profitability $\pi$ is determined by the productivity cost difference per unit of capital and the spending on last periods loan, which is determined by the interest rate $i$ and the loan taken $l$ in the last period by the firm:

$$
\begin{aligned}
K_{i(t+1)} & =I\left(\frac{P_{t} A_{i(t+1)}}{c}, \frac{Q_{i t}}{Q_{t}}, \pi_{i t}, \delta\right) K_{i t}+(1-\delta) K_{i t} \\
\pi_{i t} & =P_{t} A_{i t}-c-i_{t-1} l_{i t-1} \\
\Gamma_{i t} & =P_{t} A_{i t}-c
\end{aligned}
$$

where $\Gamma_{i t}$ represents a firm's gross profit and $\pi_{i t}$ denotes net profit after interest paid. The probabilities of drawing better technologies are due to imitation and innovation respectively and depend positively on the firm size, i.e. the amount of capital, some positive factor $a^{i m}, a^{i n}$, and the usage of R\&D spendings $\Phi$

$$
\begin{aligned}
& \operatorname{Prob}\left(d_{i m t}=1\right)=1-e^{-a^{i m} K_{i t} \Phi_{i t} \kappa_{i t}} \\
& \operatorname{Prob}\left(d_{i n}=1\right)=1-e^{-a^{i n} K_{i t} \Phi_{i t}\left(1-\kappa_{i t}\right)}
\end{aligned}
$$


where $\kappa_{i t}$ is the share which allocates funds to imitation. ${ }^{31}$ Assume that a firm does either imitation search or innovation search only. Let this depend on whether it actually employs the best technology already or whether it uses less efficient technology. The rationale is that a technology leader has nothing to copy from and can thus devote all financial means of research to innovative search. ${ }^{32}$ Firms with less efficient technology would then strictly search any possibility to copy existing technology. This is a drastic statement but also very simple. A precondition for this action is that there is common knowledge about the highest technology. ${ }^{33}$ Therefore,

$$
\kappa_{i t}= \begin{cases}0, & \text { for } A_{t}^{\max }=A_{i t} \\ 1, & \text { else }\end{cases}
$$

Credit would be demanded (only) if investment cannot be financed otherwise, that is by using net profit $\pi_{i t}$ and savings from the end of the prior period $S_{i t-1} / K_{i t}$. A firm desires physical investment (capital) according to the function

$$
\begin{aligned}
I_{i t}^{d} & =1+\delta-\frac{\mu_{i t}}{\frac{P_{t} A_{i(t+1)}}{c}} \\
\mu_{i t} & =\frac{\varphi-(\varphi-1) s_{i t}}{\varphi-\varphi s_{i t}} .
\end{aligned}
$$

where $\mu_{i t}$ is the markup power a firm could exert. This markup consists of some parameter $\varphi$ and the current market share of a firm $s_{i t}$. The higher the market share, the higher is the markup. ${ }^{34}$ The investment desire then depends negatively on the markup and positively on the price-over-cost margin of the firm. That is, the higher the market share, the less investment in physical capital is desired and the higher the profitability, the higher the desired investment since the profitability directly depends on the price-over-cost margin. Together with R\&D demand $\Phi_{i t}^{d}$ the firm has demand for expenditures $E_{i t}^{d}=\Phi_{i t}^{d}+I_{i t}^{d}$. Denote $C_{i t}=$ $\pi_{i t}+S_{i t-1} / K_{i t}-l_{i t-1}$ as liquidity per unit of capital. It consists of net profits, accumulated savings and recent credit to be paid back. By assuming a strict hierarchy in financing, a firm would first use profit to finance investment and then refer to its savings. If investment desire exceeds liquidity, i.e. net profit minus old debt obligations plus savings, there is demand for

\footnotetext{
${ }^{31}$ These probabilities are inspired by Dosi et al. 2011.

${ }^{32}$ The particular role both, innovation and imitation play in economic growth is subject to a lot of discussion and research. While innovation breaks ground to better techniques, the diffusion of this techniques as firms reorganize usually leads to the real push in economic activity. See for example, Fagerberg and Verspagen (2002) for some discussion.

${ }^{33}$ Other models employ a more sophisticated and incremental choice between imitation and innovation effort which then does not require common knowledge. See, for instance, Colombo et al. (2012).

${ }^{34}$ See Winter (1984), p. 319.
} 
additional cash in the form of credit. Credit demand is the difference needed for financing

$$
l_{i t}^{d}=\left\{\begin{array}{l}
E_{i t}^{d}-C_{i t} \text { for } C_{i t}<E_{i t}^{d} \\
0 \text { else }
\end{array}\right.
$$

The bank might offer credit based on a set of firm features. There is an overall supply for credit which leads to an average supply in terms of per unit of capital $l_{t}^{s}$. In this context besides the profitability this could be market share and also recent innovation success.

$$
l_{i t}^{s}=\left\{\begin{array}{l}
l_{t}^{s} \frac{\sum K_{i t}}{K_{i t}}\left(\lambda \frac{\pi_{i t-1}}{\sum \pi_{t-1}^{\text {pos }}}+(1-\lambda) \frac{Q_{i t-1}}{\sum\left(Q_{i t-1}\right)}\right) \text { for } \pi_{i t-1}>0 \\
l_{t}^{s} \frac{\sum K_{i t}}{K_{i t}}(1-\lambda) \frac{Q_{i t-1}}{\sum\left(Q_{i t-1}\right)} \text { else, }
\end{array}\right.
$$

where $0 \leq \lambda \leq 1$ and $\sum \pi_{t-1}^{p o s}$ is the sum of all profits from firms that yielded positive profits. The first part of the term refers to the average credit supply per unit of capital and the second one determines an increase or decrease for an individual firm according to its profitability and market share. This concept hence avoids some potential problems for the case that -due to negative profits- some firms' profits are huge relative to the average profit. Thus, the bank takes into account relative profitability and relative technology level. This also means that the available amount of credit, $l_{t}^{s}$, is not used to $100 \%$ in most cases as firms with negative profit are only offered a share computed by $(1-\lambda)$ times the market share. Assuming that the credit supply per unit of capital is fixed, the absolute amount of credit offered will grow in the total amount of capital in the industry. As $l_{i t}^{s}$ is the credit offered to individual firms in units of capital, the factor $\frac{\sum K_{i t}}{K_{i t}}$ is applied to the fixed credit supply factor. Starting with a fixed supply of credit, the credit is allocated among the firms applying for it. Then,

$$
l_{i t}=\operatorname{Min}\left[l_{i t}^{d}, l_{i t}^{s}\right]
$$

This means that even if profits are negative and there is no liquidity, $R \& D$ can be conducted up to the amount of credit. The investment constraint is

$$
I_{i t}^{c}=C_{i t}+l_{i t}
$$

Actual physical investment is then determined by this constraint and the desired investment. Actual $R \& D$ investment is furthermore determined by the amount of liquidity not used for physical investment and the $R \& D$ desire

$$
\begin{aligned}
I_{i t} & =\operatorname{Min}\left[I_{i t}^{c}, I_{i t}^{d}\right] \\
\Phi_{i t} & =\operatorname{Min}\left[I_{i t}^{c}-I_{i t}, \Phi_{i t}^{d}\right] .
\end{aligned}
$$


The firms save money not invested. Savings evolve according to ${ }^{35}$

$$
S_{i t}=S_{i t-1}+\left(\pi_{i t}+l_{i t}-I_{i t}-\Phi_{i t}\right) K_{i t}
$$

Note that savings are not noted in units of capital and cannot be negative. Firms determine their R\&D effort according to prior success of research and in boom times the firms tend to increase $R \& D$. Denoting $\Phi_{i t}$ the per unit of capital $R \& D$ spending of a firm $i$ at $t$, the firm changes $R \& D$ spending according to the factor $\Omega$. Desired spending on $R \& D$ is

$$
\Phi_{i t}^{d}=\operatorname{Max}\left[\Phi_{i t-1}\left(1+\Omega_{i t}\right), b^{R D}\right]
$$

with

$$
\Omega_{i t}=\lambda^{F}\left(\pi_{i t-1}-\pi_{i t-T-1}\right)
$$

where $T$ is the number of periods that the firm is looking back and $\Omega$ increases in the evolution of profits, the R\&D success history, and market share as that is directly incorporated in profitability. Furthermore, $b^{R D}$ is some basic R\&D activity always desired to be undertaken. This behavioural rule is intended to capture increases in $R \& D$ if times are $\operatorname{good}^{36}$ and the abandoning of R\&D if it lacks success or if competition is too tight which reduces profitability. ${ }^{37}$ Note that there will be always a non-zero level of desired R\&D which does not completely match with the statement of Yildizoglu that firms without R\&D success will abandon research completely. Note also that, compared to the Nelson-Winter approach it is just profit and savings that determine investment possibilities. In the Nelson-Winter approach the constraint is extended to the remedy of the depreciation. However, it is not clear where the funds may come from. Therefore, the pure constraint seems reasonable from that perspective. Note also that possible R\&D spending is already accounted for in the (net) profit.

Entry takes place according to a two-stage process. First, there is exogenous activity and thus the number of potential imitators and innovators is determined. Then, those draw a random technology. A constant for innovation $N=0.05$ and imitation $M=0.05$ determines the number of potential entrants for innovation and imitative behavior. After drawing an individual technology, entry takes place if the potential entrant has drawn at least the currently average technology. The other features of the entrants like capital are then further determined randomly under a uniformly distributed probability within the range of existing firms' features. A special case applies to the R\&D policy since a new firm does not have a history yet. Assume that entrants also apply the strategy $\Phi^{i n i}$ as well.

\footnotetext{
${ }^{35}$ See Colombo et al. (2012), pp. 88,89.

${ }^{36}$ Ben-Zion (1984).

${ }^{37}$ Yildizoglu (2002).
} 


\subsection{Main Driver of the Model}

The driving force of the model is the difference in technology which determines the relative profitability. According to an adjustment in firm sizes and therefore output, firms face market pressure due a decrease in price as a result of the change in output.

- R\&D fosters the productivity level $A_{i t}$ for firm $i$ at time $t$.

- $A_{i t}$ improves the price-over-cost margin for the next period.

- A better anticipated p-o-c margin spurs the desired expansion.

- In the following period, the firm will increase output ceteris paribus. This contributes to overall output and drives down the market price. The firm with better technology benefits because the technological advantage always outweighs the price decrease for non-monopolists. Other firms suffer from the lower price under given individual technology.

- The firm with improved technology gains market share and higher profits.

- According to credit supply rules, the improved technology firm is offered more credit. Hence it can grow. Other firms are offered less credit and have also less desire to invest and shrink. Both, the credit constraint and the lower amount of capital decrease the firm's probability of finding a technological improvement.

- The longer there is a gap in technology, the more concentrated the industry will become.

Those events are subject to enough financial means. Due to the hierarchy, R\&D is only possible after all physical investment that is desired is satisfied. Therefore, if there are any funding shortages, R\&D is impossible most of the time or only possible to a narrow extent. This is in line with findings that $R \& D$ reacts the most sensitive of all investment to funding shortages. ${ }^{38}$ If there is enough funding available, either due to retained profits or credit, a given change in a firm's technology triggers more pressure on the competitors if this is a very big firm. Since output increases relatively more in this case the price is driven down significantly. There are two channels at work in the dynamics of the model: firm size via investment and technology via $R \& D$. Both determine a single firms' output and thus the overall price level in the industry (indirect feedback).

\footnotetext{
${ }^{38}$ See for example Mohnen et al. (2008).
} 


\subsubsection{Converging vs Diverging Forces}

The main mechanism in the Nelson-Winter model would lead to a steady state market which means that the behavioural rule of investment desire has a converging effect. This is due to the influence of the market share: the higher the market share, the less investment is desired. Furthermore, a better technology always increases investment desire because it always improves the price-over-cost margin, except in the monopoly case where it has no effect. Given the linear price structure, for a firm in a non-monopoly market, increasing technology always increases profitability.

$$
\begin{gathered}
\frac{\partial \pi_{i t}}{\partial A_{i t}}=\mathcal{M}\left(\sum Q_{-i t}+K_{i t} A_{i t}\right)^{-1}+\mathcal{M} A_{i t}\left(\sum Q_{-i t}+K_{i t} A_{i t}\right)^{-2} \cdot(-1) K_{i t}>0 \\
\Leftrightarrow\left(\sum Q_{-i t}+K_{i t} A_{i t}\right)=Q_{t}>A_{i t} K_{i t}=Q_{i t}
\end{gathered}
$$

since $\left(\sum Q_{-i t}+K_{i t} A_{i t}\right)^{-2}$ is positive with $\mathcal{M}$ as market size. In case of a monopoly, $Q_{t}=Q_{i t}$ and $\frac{\partial \pi_{i t}}{\partial A_{i t}}=0$.

Also, in a non-monopoly situation, higher technology always increases the market share of a firm. This can already intuitively seen as the change in output due to higher technology always is bigger relative to the change in aggregate output. Thus, for the market share calculation $A_{i t} K_{i t}$, the numerator increases to a larger extent than the denominator and the entire term will thus increase. In the monopoly case the change is zero.

The finding of a better technology has a positive effect for the successful firm. Nevertheless, the availability of credit determines how severe the positive impact will be. This is an important feature of this model and in line with the findings of Lee and Harrison (2001) who claim that the benefits from R\&D and even innovation often are effective after some time lag and which then influence further R\&D behaviour. ${ }^{39}$ A better technology found in period $t$ leads to immediately increased desired investment in $t$. Then, this leads to a higher level of capital in $t+1$. Both, better technology and more capital boost output of the finding firm in $t+1$ with an increased market share. Because also total output will increase, the market price decreases. Then, the availability of credit determines how much the market share and profitability change until $t+1$. Furthermore, market share and profitability in $t+1$ determine the further availability of credit from period $t+2$ on. If there is enough credit available in $t$ the increase in output will be large because desired investment is completely satisfied. At the same time, the profitability following in $t+1$ will be comparatively low due to the price mechanism. If there is a credit shortage and investment cannot be done to the full extent desired, the impact on output will be lower; but because the price decrease is not as severe the increase in profitability is more pronounced. Therefore, the availability of credit in $t+2$ is influenced by the availability of credit in $t$. In $t+2$ then, the bank policy $(\lambda)$ matters because it is crucial whether the emphasis is on market share or profitability.

\footnotetext{
${ }^{39}$ See Lee and Harrison (2001).
} 
Thus, financing constraints at the time of a successful innovation/ imitation can hinder the economic success of R\&D and henceforth set back further increases in the R\&D effort.

\subsubsection{Small Firms vs Large Firms}

Small firms react less on improvements of technology in absolute terms because their markup $\left(\mu_{i t}\right)$ is smaller. Their desired investment changes less if the market share is low. Furthermore, since investment is in terms of per unit of capital, the absolute change for any given rate of desired investment is lower for small firms. Therefore, due to their low level of capital, even a large investment per unit of capital is only of limited effect on output and price. However, via this price mechanism the profitability of small firms improves more significantly compared to large firms. This has a direct effect on the following R\&D desire of the small firm.

Therefore, smaller firms tend to improve their profitability rather than their size compared to large firms as a direct result of a successful innovation/ imitation.

\section{Simulation Results}

The model is carried out by a computer simulation in a heterogenous agents framework. The common features of the single experiments are given by the parameter setup

\begin{tabular}{cc||cc||cc||cc||cc}
\hline$D_{t}$ & 1000 & $\delta$ & 0.03 & $b^{R D}$ & 0.002 & $\Phi_{i t}^{0}$ & 0.004 & $a_{i t}^{i n}$ & 0.007 \\
& & & & & & & & & \\
& & 0.16 & $\varphi$ & 3 & $K_{i t}^{0}$ & 140 & $a_{i t}^{i m}$ & 0.02 \\
\hline
\end{tabular}

where there are 100 runs for each value of a varied parameter. The initial number of firms is 10 , the interest rate is $2 \%$, the bank policy $\lambda=0.5$ and firms' policy $\lambda^{F}=2$. The results are taken from an average between the periods $t=280$ to $t=300$. For the experiments, the credit supply is chosen according to a critical level of credit supply that might just cover credit demand. In order to find an appropriate level, credit surplus for the above setting is looked at for a range of credit supply. Figure 1 shows the lowest level of credit supply that yields positive excess credit supply for 100 simulations where for each repetition $l^{s} \in[0.02,0.05]$. The mean is 0.030404 with a standard deviation of 0.00422135 . Results range from 0.02 to 0.0374 . For the experiments concerning market conditions, credit supply is fixed to $l^{s}=0.03$ which is credit supply per unit of total capital in the industry. For the policy experiments this level is refined a little bit more to $l^{s}=0.027$. 


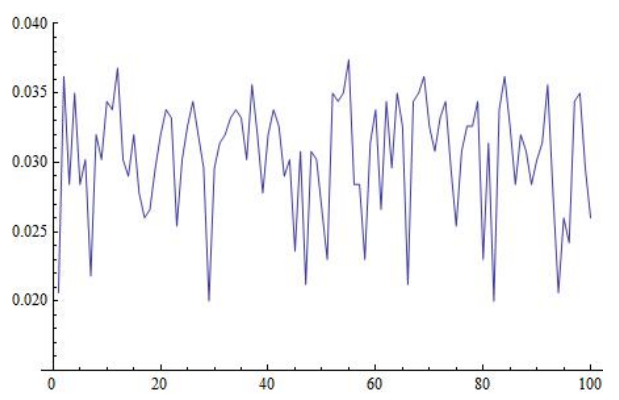

Figure 1: Lowest level of credit supply that generates positive excess credit supply.

In a situation without any external financing opportunity, technology does not improve at all since the firms earn just the depreciation rate and can only replace written off capital. If entry does take place, competition increases and firms earn even less than depreciation. There is no improvement at all but the firms decrease in size over time as the market is fixed. In either situation there is no funding for R\&D available. ${ }^{40}$ In this section the effects of credit supply and the interest rate are examined first. For the estimate of the diffusion of technology, we refer to the technique of computing the GINI-coefficient in order to yield a measure of concentration. This means that a low level of diffusion goes along with a high concentration number which is between zero and one. Furthermore, it will be interesting to look at the concentration of output, that is monopoly power which is measured by the Herfindahl Index. Also, the evolution of overall industry output gives insight on the effects under investigation. For comparison, we will manipulate parameters of importance and check whether long run results differ according to that changes. After, the effect of credit supply and the interest rate are examined, the firms' and banks' behaviour is subject to examination.

\subsection{Market Conditions}

The market conditions that govern the outcome are credit supply, interest rates and demand. Demand determines the severeness of competition in an industry but is not really a constraint like credit supply or the interest rate. Constraints of financing can originate in

- no source of financing,

- a slow setting up of financing or

- a too high interest rate. ${ }^{41}$

\footnotetext{
${ }^{40}$ It is debatable whether firms with credit shortages will do no R\&D whatsoever for all times. It might occur that they shift to an R\&D priority after a while in order to improve somehow, even if the company must shrink severely initially.

${ }^{41}$ Savignac (2007), p. 6.
} 
For a French sample, from all restraint firms, as much as $88 \%$ had no financing source for their project, and $22 \%$ faced a too high interest rate to conduct a successful implementation of their project. ${ }^{42}$ Schumpeter $(1939,1941)$ points out that in a competitive environment, probably no firm does yield enough profit as to perform R\&D. It is only the monopolist who can set aside enough money and thus take research action. ${ }^{43}$ In this model, a monopolist or the sole user of state-of-the-art technology can exert pressure via the productivity of his capital which will exceed costs more the higher his technology out-stands his competitors' one. Increased production lowers the price and therefore the technological monopolist has a comparative advantage which yields above average profits.

\subsubsection{Credit Supply}

The expected impact of credit supply is that the more credit is available, the easier is financing investment and the better the industry can evolve. A representative run for a high level of credit supply $\left(l^{s}=0.3\right)$ reveals that innovation takes place more often and the phases of diffusion where concentration slowly decreases are interrupted many times (see figure 4). If there is no credit whatsoever, neither innovation nor imitation takes place. This is due to the fact that the competitive market does not allow for abnormal profitability in a situation where every firm is the same in the first place (see figure 3). Firms need all their profits to reinvest into physical capital in order to counter depreciation. Entering firms with the same technology then add more pressure to the price and firms can only downsize. There is an equilibrium situation where the firms have just the size that joint output yields a price that ensures a price-over-cost margin of the amount of depreciation. If no firm would enter, technology would be fixed as would be firm sizes, output, and price.

If less credit is available at the time of a successful draw $t$, then the increased desire for investment might not be met fully and neither does the firm grow too much nor does it conduct any $R \& D$ in the following period. Hence, the impact on market share is humble but the change in profitability is rather high. Consequently, R\&D desire in $t+1$ will be high but investment desire might be comparatively low because of the increased market share and the higher price-over-cost-margin. Credit supply, at this point is still not influenced fully because it looks back one period and will thus only be effective in response to profitability in $t+2$.

The effect of higher credit supply is distinct (see figure 2). Specifically, there is a critical value of credit supply which allows the economy to evolve much different, i.e. there is a jump in the dependent value. Without credit supply firms have demand for R\&D but cannot do it because their investment in capital does not leave any funds for additional investment in R\&D. With the strict hierarchy in place that physical investment comes first, there is almost never any

\footnotetext{
${ }^{42}$ See Savignac (2007), p.7.

${ }^{43}$ Schumpeter $(1939,1941)$.
} 

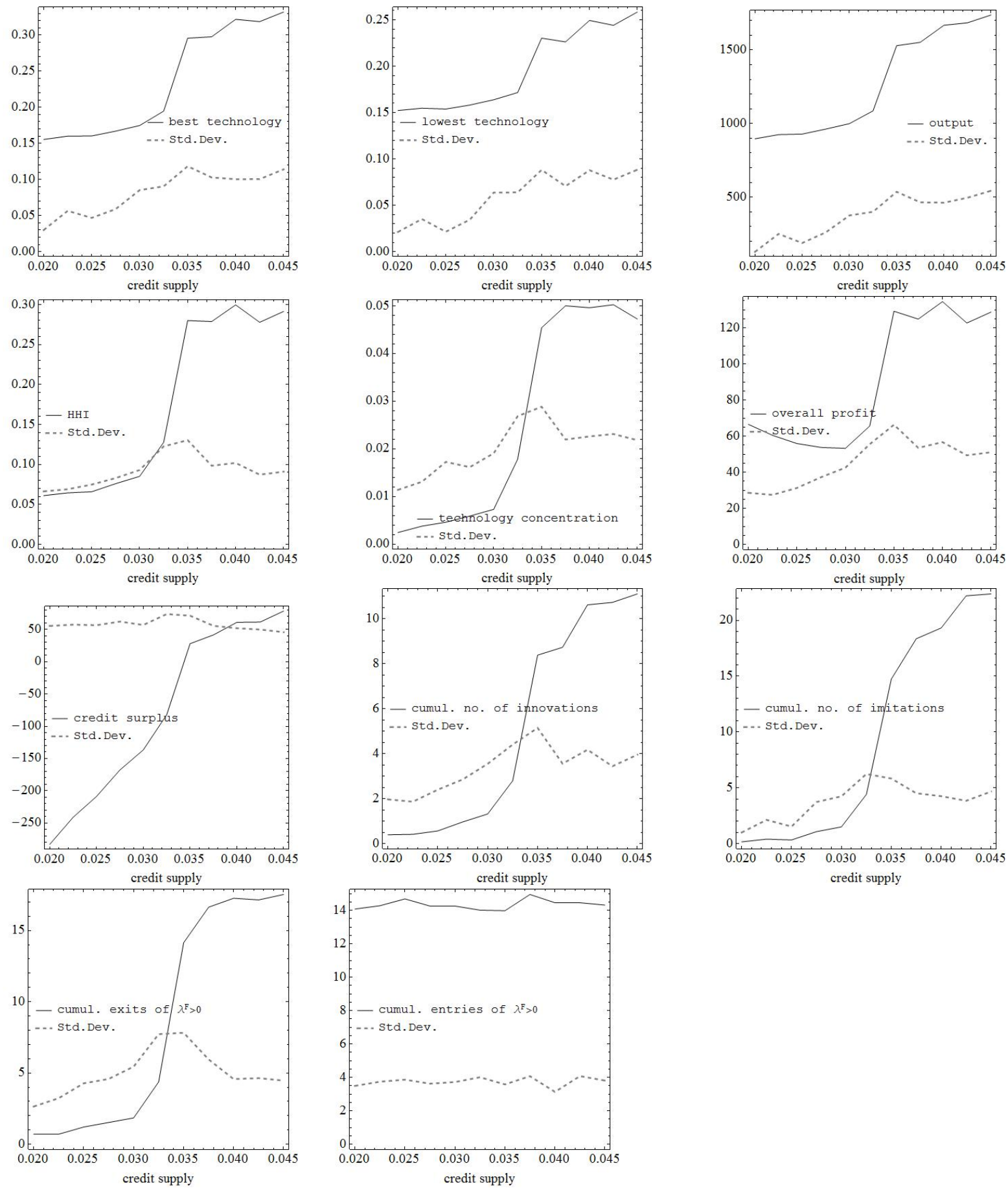

Figure 2: Impact of credit supply 


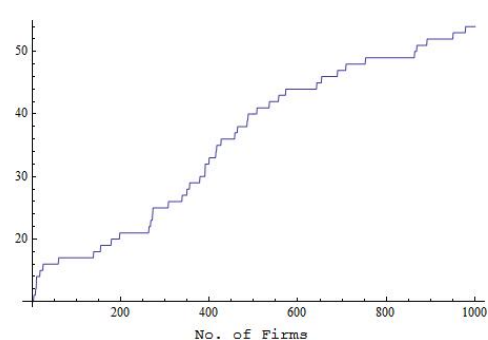

Number of firms

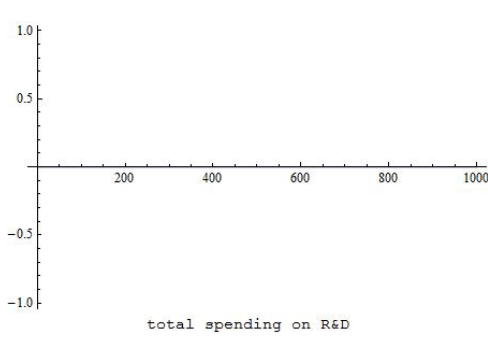

Average R\&D spending

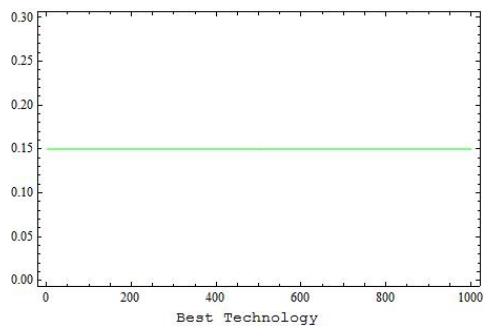

Best technology

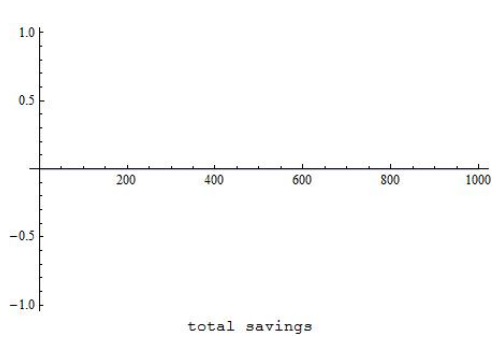

savings (total)

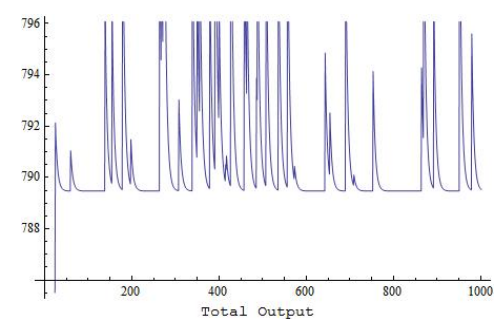

Industry output

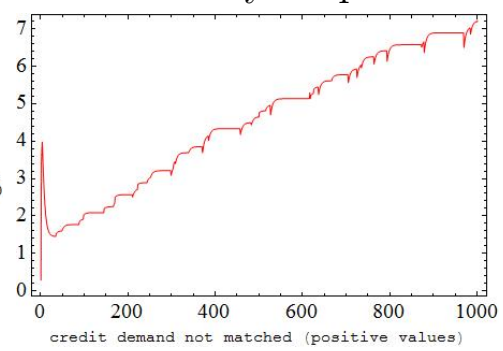

unsatisfied credit demand

Figure 3: Representative over time evolution with no credit available.

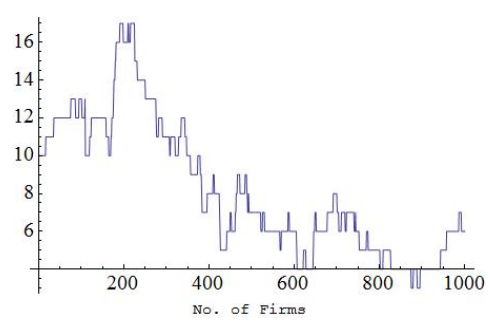

Number of firms

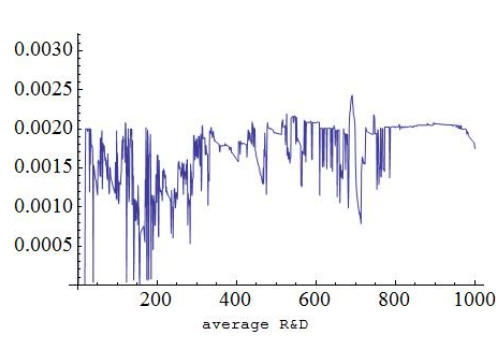

Average R\&D spending

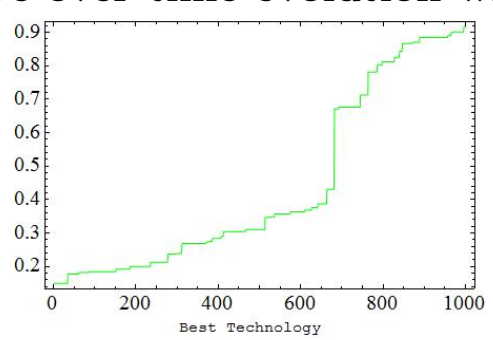

Best technology

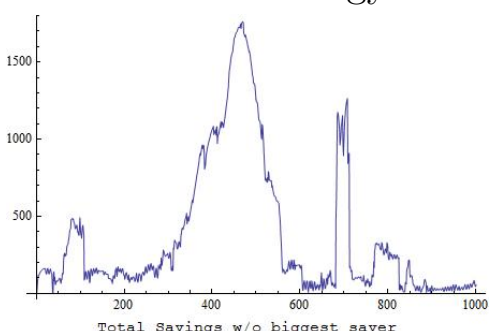

savings w/o biggest saver

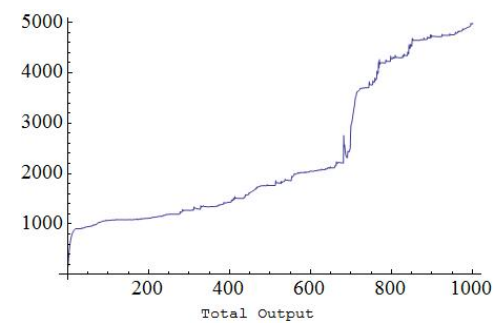

Industry output

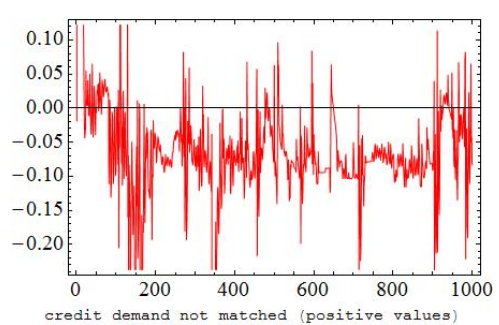

unsatisfied credit demand

Figure 4: Representative over time evolution with credit available $L^{s}=0.03$.

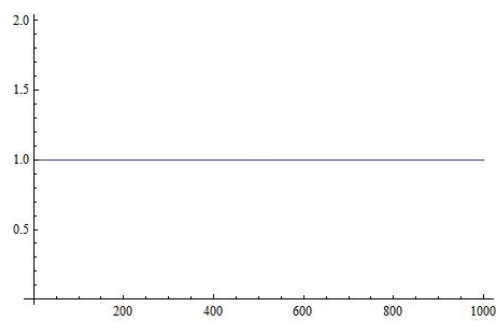

$L^{s}=0$

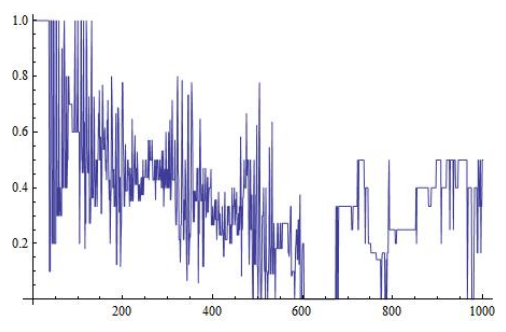

$L^{s}=0.027$

Figure 5: Share of firms that face constraints in financing over time 
funding of R\&D and thus technology does not improve (see figure 3, upper left). The negative credit surplus in the same figure (3rd row, left) indicates that firms very well would invest more but are effectively constrained. As they only outbalance their depreciation, no firm grows and as new firms keep entering the economy, competition becomes tougher and brings down prices and hence profit. Therefore, firms find it harder over time to outbalance depreciation and the result is that firms shrink and concentration decreases (see $\mathrm{HHI}$ in that figure). If firms can access the funding they desire, which is indicated by more and more credit surplus, R\&D can effectively be conducted and there are technological improvements (figure 2, 3rd row middle and right image). This creates firms that have a better price-over-cost margin than other firms and those firms hence yield more profit and grow. They also gain market share. This puts further pressure on firms with inferior technology as the price is pushed down. Some firms leave the economy (figure 2, lower left) which relieves the market from price pressure a bit. As more credit is available, the level of technology is increasing faster and the overall output is higher (figure 2 upper right). As a consequence, there are fewer firms dominating the market. Technology diffuses less in credit supply because bigger firms can excert more pressure on the price via output. This does not leave much profit for laggard firms to invest in R\&D. Larger firms also absorb more of the credit supplied in total which also hurts laggard firms' ability to spend funds on R\&D.

There is a jump in the dependent values as credit supply increases. This is due to the fact that at some point enough credit supply will facilitate and promote further credit availability which then leads to a different trajectory of the economy. Only if there is enough credit supply, a technology improvement pays off to the full extent over time. In keeping the level of R\&D desire also high, credit supply is crucial for the actual $R \& D$ effort undertaken in the aftermath of successful technology improvements.

Figure 5 shows that credit supply results in a lower relative number of firms that are actually constrained in credit. This is partly due to some firms accumulating savings and thus not demanding credit and partly due to a shake out period leaving only the more successful firms.

\subsubsection{Interest Rate}

The next experiments are conducted for $i \in[0,0.2]$ and $l^{s}=0.03$.

The interest rate has an intuitive effect: the higher the interest rate, the less profitable are firms. If there is an effective credit constraint and no Ponzi-scheme possible, a high interest rate leaves firms spending more and more on the credit and less funds are left for conducting $R \& D$. This is visible in the overall profit that is decreasing in the interest rate. As profits are lower, the firms demand for credit in order to finance their endeavors. Therefore, credit surplus is decreasing in the interest rate (figure 6, 3rd row left). However, the impact of the interest 

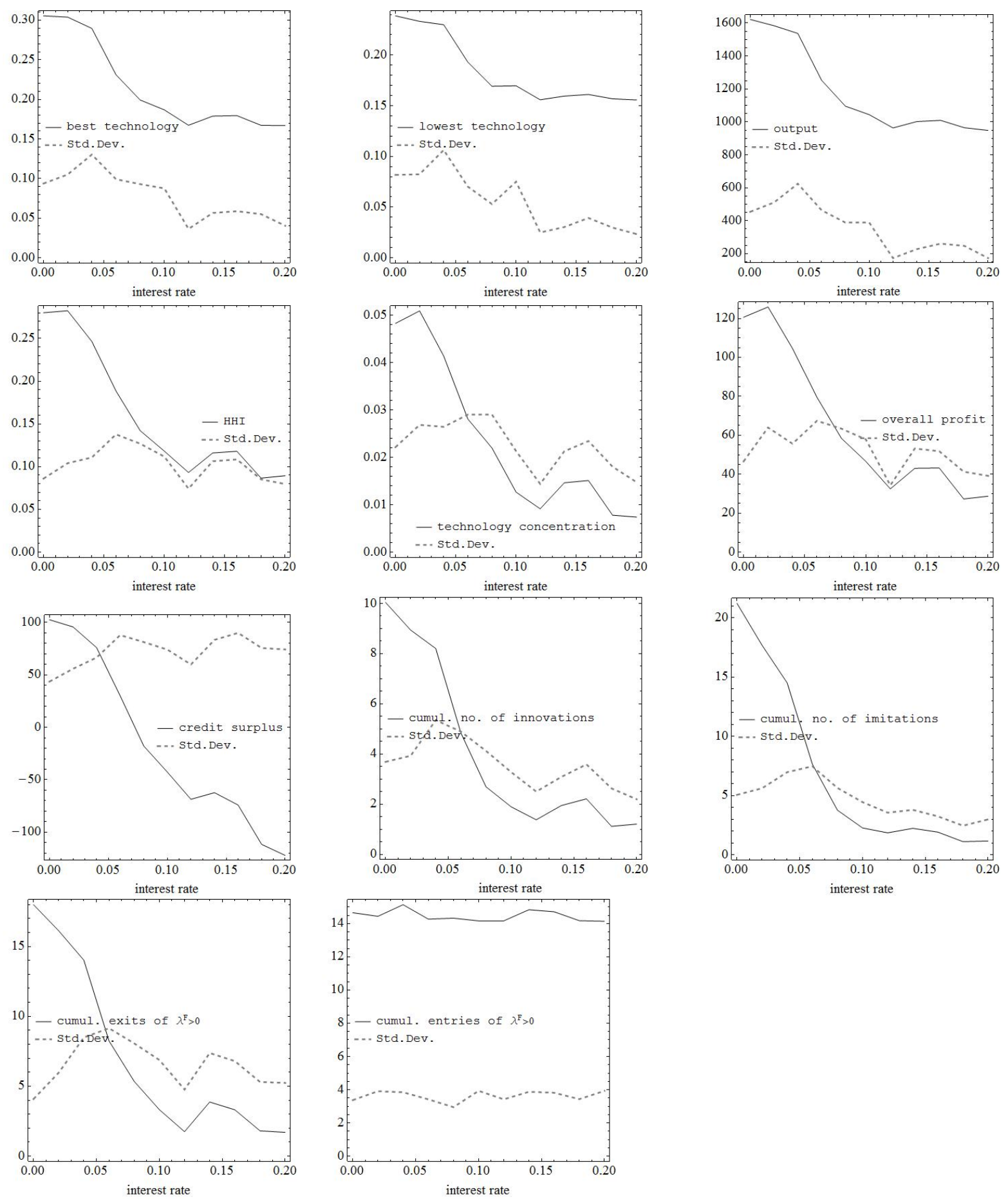

Figure 6: Impact of the interest rate 
rate is rather continuous. As credit supply is given but varying for firms, lower profits mean a more effective constraint in financing on average. Therefore, less innovation and imitation takes place economy-wide. Along with a lower technology level, output is lower and prices are higher. Nevertheless, less innovation and imitation leaves the firms to be more equal. No firm is able to excert enough pressure to drive competitors out of the industry, which is visible in the lower exit rates in the interest rate (figure 6 lower left). The images about technology concentration and the Herfindahl index deliver further evidence for firms being more equal in higher interest rates.

Therefore, the costlier credit, the less imitation and innovation actually is observed.

\subsection{Policies}

There are two ways in which the behaviour of the agents can influence the dynamic: the bank's weighing of firm features in offering credit and the intensity of change of the firms' R\&D adaptation rule which affects $\Omega$. The bank's policy is the main matter of interest. It determines the financial constraint any individual firm is facing. Although the overall credit supply does influence the individual access to credit, it is the bank's policy that accounts for the differences within credit supply. The key question addressed is to what extent the bank's policy promotes a particular outcome, that is, whether it has only a small influence or whether it can change the dynamic of the industry rather completely. While the empirical evidence mentioned in section 2.2 indicates that firms are behaving pro-cyclical in setting their $R \& D$ rule, it is possible to see which effect a counter-cyclical behaviour can have. Furthermore, it is possible to account for the impact that the intensity of their behaviour can have. Empirics also point at rather static rules due to relatively high costs of change in R\&D settings. It is hence possible to check whether a higher flexibility in adapting to financial conditions would be likely to benefit the industry as a whole.

\subsubsection{Bank's Policy}

The bank assesses creditworthiness according to two pieces of information: collateral and profitability. Collateral provided by the firm is represented by the market share and profitability is proxied by expected cash flow. Market share can represent collateral if the stock of products would be considered as to be pledged. This relies less on the machinery as collateral but on the final product. The cash flow expectation is represented here in the simplest fashion possible. Since banks use heuristic concepts to a large extent for the assessment of the firm prospects, this is captured by the one-period focus on profitability. In reality, several periods of profit would be taken into account. As the bank's policy is a mix between evaluating the 
collateral amount by looking at the market share and forecasting cash flow by looking at the profitability, its policy can be described by the weighing parameter that determines the impact of each piece of information on the credit decision.

If there is sufficient credit supply at the time a new technology is found, there is a huge impact of the finding on further credit availability in case the bank puts emphasis on collateral. Since the access to credit at the time of the finding allows for a significant investment and thus increase in capital, the firm will grow significantly. Therefore, firm size at $t+1$ is relatively large as is market share. Then, in $t+2$ this matters for the further availability of credit. If the focus is on firm size, the effect of the initial technology improvement on further availability of credit is significant. If the focus is on profitability, the following credit supply is comparatively low because the massive increase in output and market share pulls the market price down which limits profitability increases in $t+1$. As the bank evaluates profitability, further credit supply in $t+2$ will be comparatively modest. If there is credit shortage in $t$, the increase in market share at $t+1$ is relatively low which leaves a higher market price in $t+1$ and a comparatively lower price-over-cost margin.

Then, if the bank looks only at collateral, credit supply in $t+2$ is relatively low and if the bank looks only at profitability, it will offer comparatively more credit in $t+2$.

Theoretically, access to credit promotes output rather than profitability because the firm translates technology improvements in physical investment immediately. In case the following output is significantly higher, the price mechanism dampens the increase in profitability.

The experiment results are depicted in figure 7. Output is a direct consequence of innovation while profitability is rather indirect. If the bank puts emphasis only on the market share $(\lambda=0)$ there is a high concentration evolving because there is a higher probability for an innovating / imitating firm that it actually can do even more research. A crucial feature for the likelihood of drawing a technology improvement is the firm size (see eq. (9)). Also, the firm size is the crucial feature for market share. The bank hence promotes mostly firms that are already doing well, which is well in line with the collateral concept. There are two reasons for a high market share: firm size and technology. Both affect the collateral value.

The credit shortage for the non-technology-improving firms reinforces the financial disadvantage. These firms are driven out of the industry relatively quickly which is indicated by the low longevity of firms and the high number of exits for the collateral focused bank policy.

This is supported by the indicator of the share of firms that is actually constrained in credit. This share is bigger for the profitability based bank policy. This second extreme case of bank policy does promote concentration as well, but this is not transmitted through all of both factors that lead to concentration: differences in technology and differences in firm size. For this profitability based policy only technology propels a faster firm growth via the aid of credit 


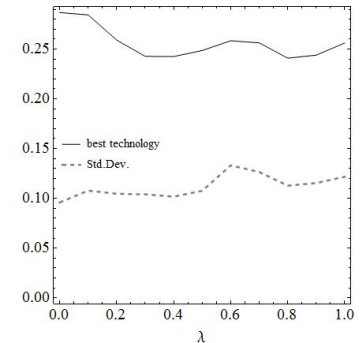

best technology

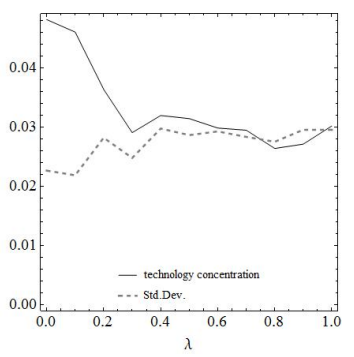

technological concentration

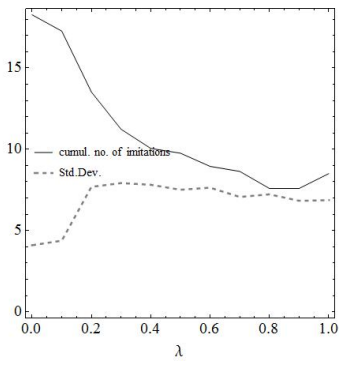

cumulated imitations

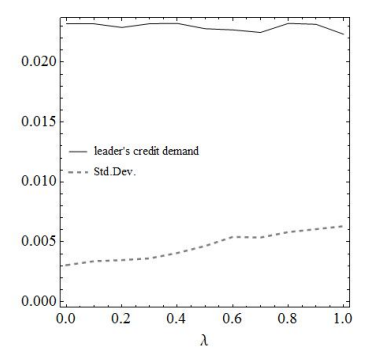

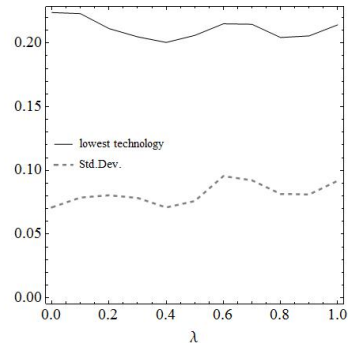

lowest technology

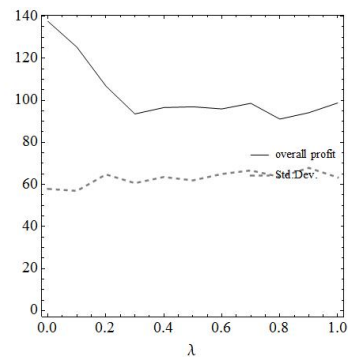

overall profit

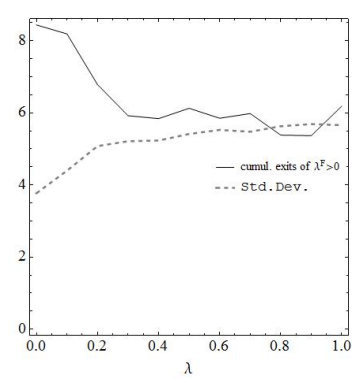

cumul. exits

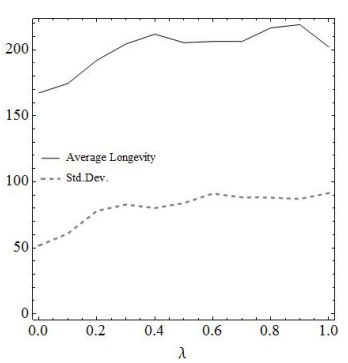

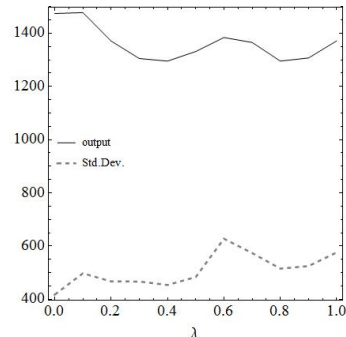

output

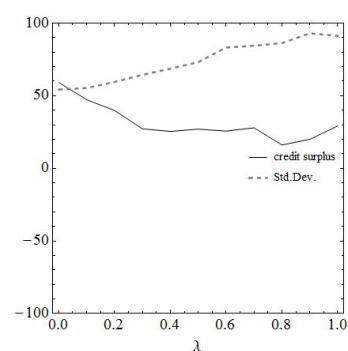

overall credit surplus

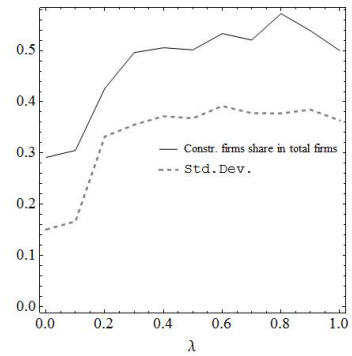

share of constr. firms

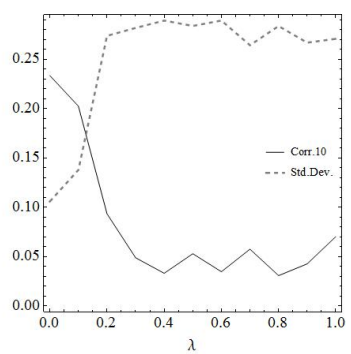

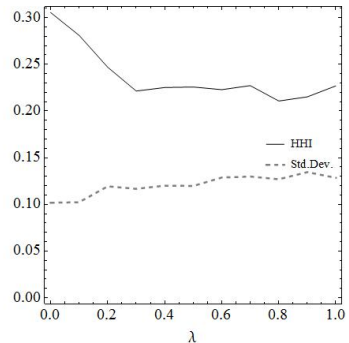

HHI

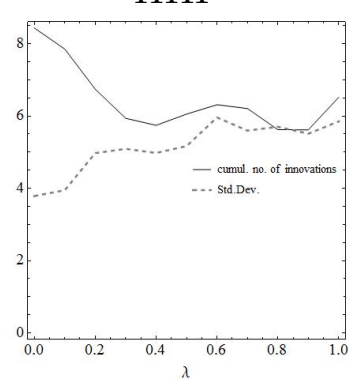

cumulated innovations

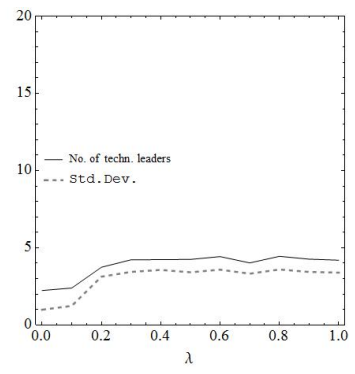

no. of techn. leaders

av. credit demand av. longevity of Correlation of techn. leader(s) firms Profit(t)-Firm

Size $(t+10)$

Figure 7: Impact of bank policy 
supply while for the collateral based approach both factors contribute to the growth advantage of a technology improving firm.

\subsubsection{Firms' Policy}

Firms decide individually how much they want to spend on R\&D. According to empirical evidence they adjust their R\&D effort to their business situation. In this model this is captured by productivity. If productivity increases, so does the R\&D desire of firms. If there were no constraints in financing $R \& D$ there would be an inherent force that would create a wedge between firms and lead to concentration. Firms who are successful would even do more R\&D and thus expand their lead. The opposite is true for less successful firms: they even would reduce their $R \& D$ activity and therefore would be even less likely to catch up. ${ }^{44}$ With financing restrictions in place this drift is less severe as firms' expansion of $R \& D$ might be dampened. The more credit constraints, the less technological improvement there will be in general. Nevertheless, even if firms pursue a different policy for R\&D according to profitability, they all increase physical investment in profitability. Along with a given technology, this already is a concentration driving force.

A higher profitability in $t+1$ after technology improvement in $t$ has an impact on the desired spending on R\&D. If the reaction of the firm is positive, any higher profitability will lead to a higher desired R\&D spending compared to the last period. Nevertheless, if following R\&D desire over two periods after an innovation, a lack of funding might set back actual R\&D spending. An increased profitability always leads to a positive tendency in the R\&D desire, but the desire also depends on the actual spending from the prior period. Therefore, a funding restriction on investment at $t$ leads to a higher desired change in $R \& D$ investment, but not to a higher level because in $t+1$ actual $R \& D$ was set back. For a full funding situation, as profitability is comparatively lower, the desired change in R\&D spending is lower but the actual level is higher. If the firms react negatively on profitability, the effect is vice versa.

The experiment conducted tracks differences out of the firms' adaptation behaviour. Results under a scarce credit supply regime are shown in figure 8. There is no distinct impact of neither the basic strategy of the firms nor the magnitude of reaction. The reason is that once a credit shortage was effective, $R \& D$ desire is set back to the basic level. Then, it does not matter too much whether the change in desire $(\Omega)$ might be high or low. Credit shortage frequently sets back the desire for conducting $R \& D$ in firms.

A comparative experiment with an abundance of credit available reveals that the firm policy would have an impact if there was sufficient credit (figure 9). Then, the severeness of reaction $\left(\lambda^{F}\right)$ would positively influence technology and output. Concentration and overall profit

\footnotetext{
${ }^{44}$ Compare the results for the different levels of overall credit supply.
} 

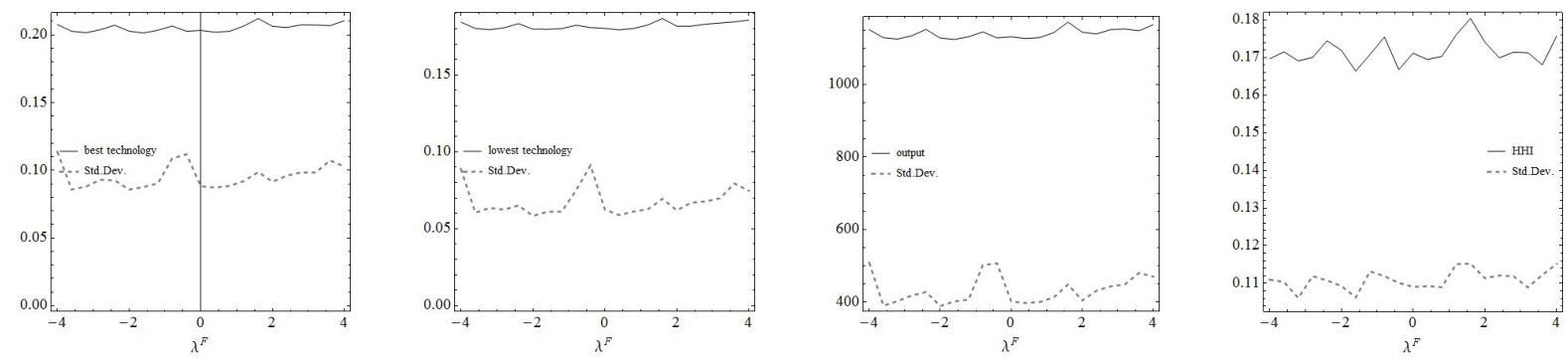

best technology

lowest technology

output
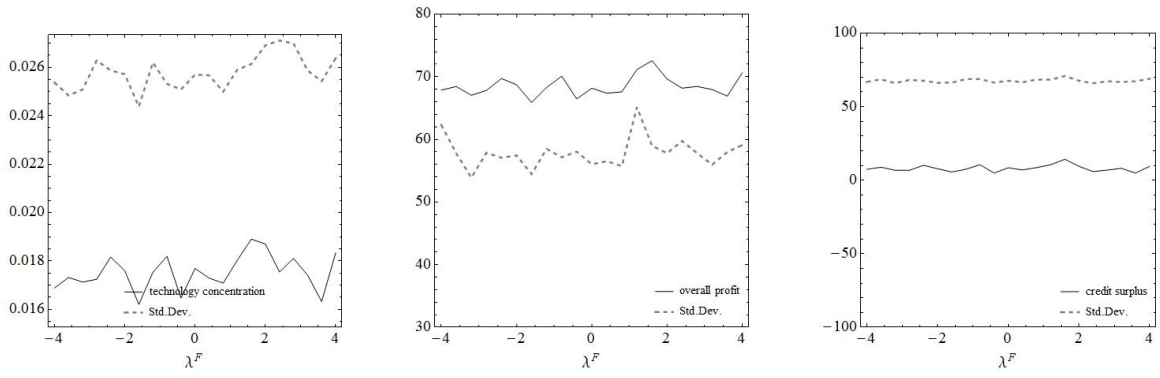

HHI

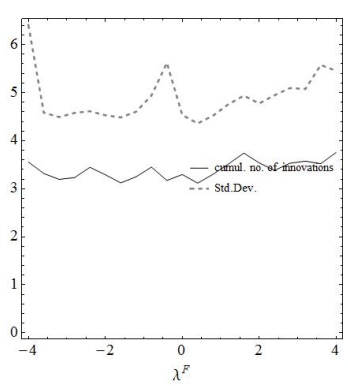

technological con-

overall profit

overall credit surplus

cumulated innovations
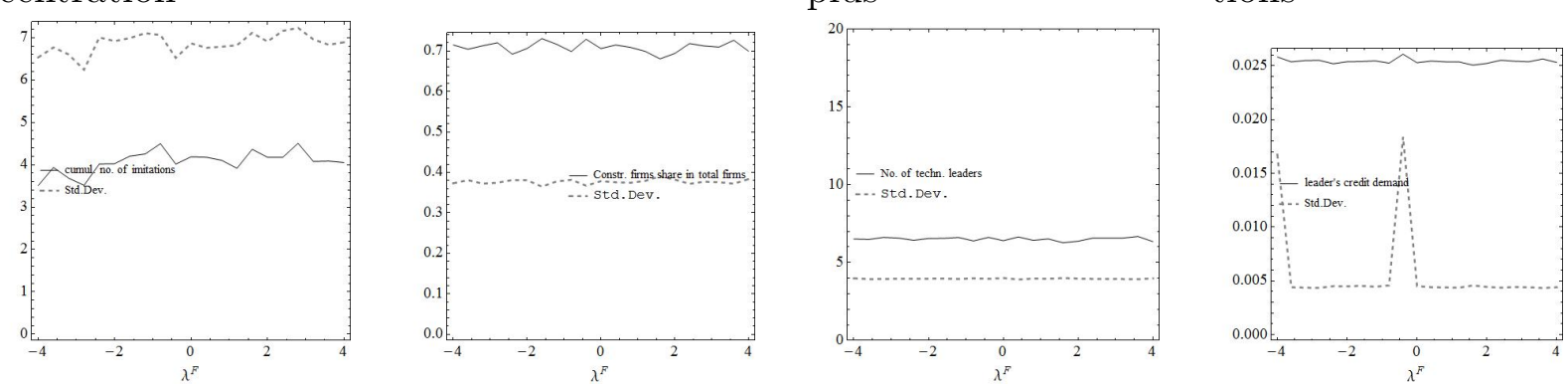

cumulated imitations

share of constr.

no. of techn. lead-

av. credit demand firms ers

of techn. leader(s)
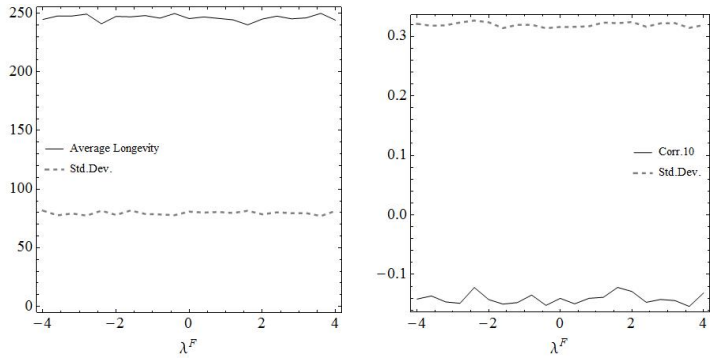

av. longevity of Correlation

firms

Profit(t)-Firm

Size $(t+10)$

Figure 8: Impact of firm rule 
would depend on the direction of the policy, that is whether the firm increases desired R\&D spending in economically favourable times $\left(\lambda^{F}>0\right)$ or whether is has a contrarian policy $\left(\lambda^{F}<0\right)$. The more firms react positively on good figures, the more profit they will make in total and the more single firms can grow with respect to their competitors. This indicates the effect of the policies on the diffusion of technology. If a contrarian firm policy is in place, technological leaders will cut spending on $R \& D$ while laggard firms will try to catch up. If credit supply is plenty they can actually spend money on R\&D and so imitation is possible. As technology more and more diffuses by imitation, the leading firms suffer in profitability and again increase their R\&D spending desire. Overall output is higher if the reaction is stronger, but concentration is lower because the laggard firms do not suffer from funding shortages and diffusion is more pronounced. This is also visible in overall profit which is low even if output and the best technology benefit from more drastic reactions. As there is more equality and less advantages for single firms, more firms stay in the industry but earn less. If credit supply is large enough, the less profit does not hinder R\&D effort as some kind of Ponzi-financing can emerge. This is a situation where further or rolled over credit is used to pay off mature liabilities like interest or credit itself because the current profitability is too low. This can be a vicious circle as further credit increases the liabilities and thus cuts into profits even more. Nevertheless, if credit supply is large enough, this situation can be sustained for a long time. For a positive reaction on profitability, leading firms try to take off even further. Due to sufficient external funding they can do so and have a high probability of drawing better technology also in the long run. Other firms cut desired spending on R\&D and diffusion is less likely. Many firms leave the industry and the concentration is higher. Overall profits and output are higher because the technological frontier is shifted significantly, but this is due to only a few (or even only one) firms. The comparison of two regimes where credit supply is critical in one case and where it is abundant in the other confirms the conjecture about the impact of the firm behaviour. If credit is scarce, it does not matter too much how a firm responds in its desire to conduct R\&D because credit shortage frequently set its desire back to the basic level. Persistent changes over time in the $R \& D$ desire are thus less probable. If there is plenty of credit, however the firms' rule matters. As credit enables firms to satisfy their R\&D desire, it can actually take paths according to the policy. Then the magnitude of reaction matters while it becomes clear that a positive feedback policy leads to concentration in the industry while the contrary strategy leads toward a more equal industry.

\subsection{Joint Effects}

The previous experiments showed the single effects of market and policy characterizations in a particular environment. These observations can be combined to a larger picture of the effects in particular circumstances. In order to check the robustness of those observations, 


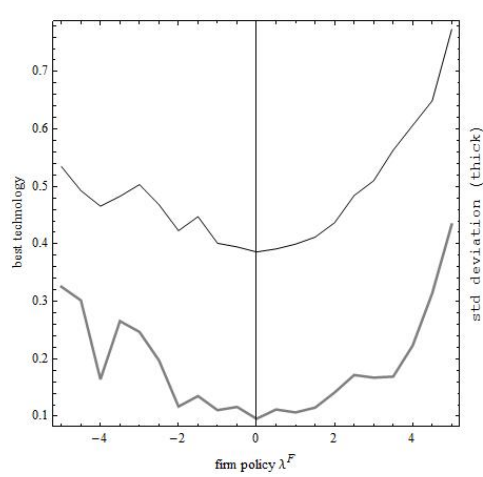

best technology

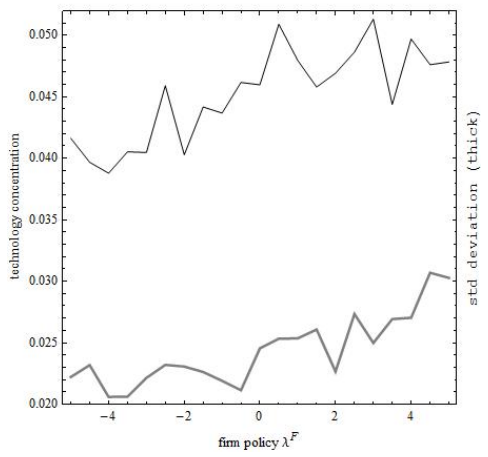

technological concentration

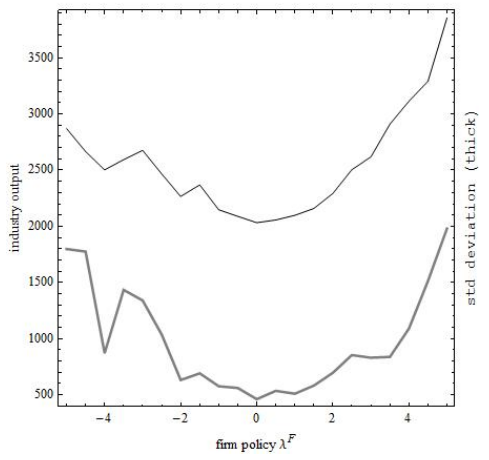

output

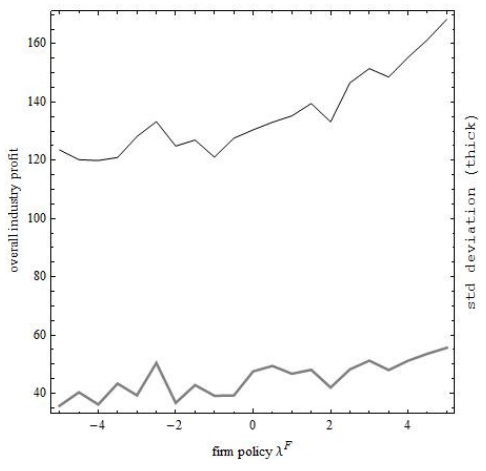

overall profit

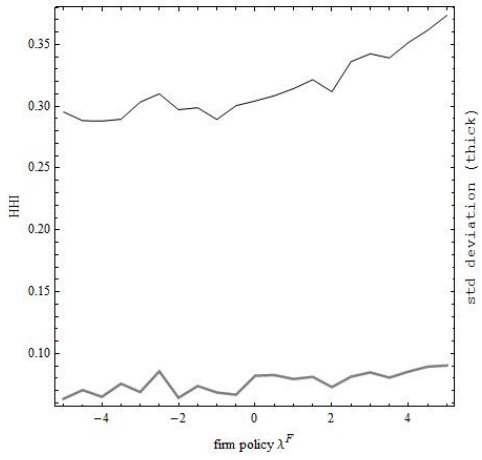

HHI

Figure 9: Effect of firm rule with abundant credit supply

a Wilcoxon-Signed-Rank test is used. This non-parametric test is done for the impact of the bank policy under 100 random market and firm policy setups for a significance level of $95 \%$. As market conditions cannot be influenced by the agents in this model, the focus is on policies. Furthermore, since the impact of credit constraints is the matter of interest, the results obtained are checked for robustness by focusing on the bank policy and comparing three levels of it. It is checked whether the results obtained from the comparative analysis hold in broader, randomly chosen parameter setups, that is, in a broader environment. The Wilcoxon-Signed Rank Test confirms the qualitative findings so that those are concluded to be robust at a $95 \%$ significance level (see appendix).

As the model is intended to capture the effects of credit shortage, the level of credit supply turns out to be the most influential part of the model. If there is a shortage, no $R \& D$ is conducted because investment in replacement and additional machinery has priority. If there is abundance of credit, firms can conduct a lot of $R \& D$ which pushes the technological frontier forward. The way credit supply is allocated is hence crucial only if credit is scarce. Then, credit is offered to a fraction of the firms while other firms are almost excluded from credit. This is the environment where behaviour has the highest impact. The bank determines which features are important for access to credit. If it puts most weight on market share, the firm policy does not have a significant effect because the firm R\&D policy only responds to profitability. Its response to market share is fixed in the investment desire function. However, as soon as the 
bank puts some weight on profitability, the firm policy gains importance. In this case both, the bank and the firm react positively to profitability, thus, there is a twofold positive feedback on profitability. It is under this circumstances - scarce credit supply and credit allocation based (also) on profitability - when it pays off for a firm to adjust R\&D desire according to profitability because the bank also reacts positively on it. It can be observed that the firm policy is more effective if credit supply is high with respect to output and concentration (see figure 9), however, this impact does not change very much in bank policy as long as there is

some weight put on profitability by the bank (- see Wilcoxon-Test results in the appendix). If there is plenty of credit available, firms can finance almost every investment and R\&D desire and the distinction by the bank still leaves enough credit supply for the least supplied firm. Additionally, firms only demand a limited amount of credit, even in periods of high intended investment and R\&D. Therefore, the bank policy does not have a significant impact in such a situation. The same is true if credit supply is too low. Then, even the best firm is not being offered enough credit to conduct R\&D on top of investment.

Thus, there is a minimum level of credit supply that is necessary to enable firms to develop over time below which, neither the bank policy nor the firm policy is of much impact. Once this level is passed, the bank policy becomes crucial. It exerts the most effect if credit supply is not as large as to allow for Ponzi-financing. Nevertheless, the firm policy is most effective in a situation of Ponzi-financing because then it is assured that it actually will be able to carry out its policy.

\section{Conclusion}

The purpose of this work was to examine in what way credit shortages can influence the evolution of an industry if technological improvement relies very much on credit and at the same time echoes back to credit availability. In a model where firms decide how much they want to invest in capital due to their market situation and how much on top they want to spend on research based on profit history it turns out that this hierarchy is sensitive to credit shortages. Market conditions - such as credit availability and interest rates - are checked for their impact on technological evolution and market concentration as well as total output. There are two policies taken into account: the bank's decision rules about creditworthiness and the firms' rule about adapting R\&D effort. The approach is based on an evolutionary model by Nelson and Winter. This heterogeneous agents based model is examined by using a computer simulation.

The main findings are that the most crucial factor is overall credit supply available in the industry. A higher credit supply is always beneficial to some extent but there is some critical level of credit supply where the impact changes dramatically, i.e. there are jumps in the dependent numbers. This is due to the fact that if there is sufficient credit supply at the time 
a better technology is found there is also further credit supply in the longer run. The interest rate has an intuitive effect in that a higher interest rate always hinders the evolution of the firms and thus the industry which is simply due to the fact that interest is costly for the firms. The bank influences the evolution of the industry by its internal routines because it can reinforce the positive effect of a new technology on the firm size via investment. The better technology is visible for the bank later than for the firm that found it and therefore it matters to what extent that technology is visible in the firm's balance sheet two periods later. If the bank considers predominantly firm size, it fosters further growth because firm size is directly affected by better technology. Thus, the impact of the better technology is more significant via firm size. If the bank looks predominantly on profitability, the impact of the better technology can be diluted. Therefore, the correlation between profitability and later firm size is bigger if the bank values firm size relatively more. Also, smaller firms will improve more on profitability than on size in comparison to large firms. Thus, if the bank values profitability more, it gives an advantage to smaller firms. This however, reduces the probability of further improvements compared to a situation where mainly large firms benefit from credit because the probability of finding better technology is positively influenced by firm size.

Firms can adapt their R\&D behaviour. This however, only influences their situation if there is plenty of credit available. In that case a positive feedback rule is more effective on the technological evolution but brings along a monopoly situation. This is due to the fact that in a negative feedback scenario, innovators stop innovating and other firms try harder to catch up. It is an inherent convergence behaviour. Nevertheless, the heftiness of reaction promotes technological evolution in both scenarios because any desire can be met if there is enough funding and profitability does not matter too much in such a situation.

This model considers only a single industry where a homogenous good is produced. There might be further insights if different industries compete for funding where the bank again assesses the probability of bankruptcy for each firm. Furthermore, it would be interesting to consider some exogenous policies, like the monetary policy of a central bank which would be effective in the model as credit supply shocks. The trajectory of the industry in response to those changes could provide insights about the effects of a particular policy on technology, market power and individual access to credit. 


\section{References}

[1] Aghion, Philippe, George-Marios Angeletos, Abhijit Banerjee, and Kalina Manova (2005): "Volatility and Growth: Credit Constraints and Productivity-Enhancing Investment", NBER Working Paper No. 11349.

[2] Aghion, Philippe, Philippe Askenazi, Nicolas Berman, Gilbert Cette, and Laurent Eymard (2012): "Credit constraints and the cyclicality of R\&D investment: Evidence from France", Paris School of Economics Working Paper.

[3] Ben-Zion, Uri (1984): "The R\&D and Investment Decision and Its Relationship to the Firm's Market Value: Some Preliminary Results", in Griliches, Z. (Ed.) R\&D, Patents, and Productivity, pp. 299-314, University of Chicago Press.

[4] Brown, James R, Steven M Fazzari, and Bruce C Petersen (2009): "Financing Innovation and Growth: Cash Flow, External Equity, and the 1990 R\&D Boom", The Journal of Finance, Vol. 64 (1), pp. 151-185.

[5] Brown, James R, Gustav Martinson, and Bruce C Petersen (2012): "Do financing constraints matter for R\&D?", European Economic Review, Vol. 56, pp. 1512-1529.

[6] Canepa, Alessandra and Paul Stoneman (2008): "Financial constraints to Innovation in the UK: Evidence from CIS2 and CIS3", Oxford Economic Papers, Vol. 60, pp. 711-730.

[7] Cincera, Michele and Julien Ravet (2001): "Financing Constraints and R\&D Investments of Large corporations in Europe and the USA", Science and Public Policy, Vol. 37 (6), pp. 455-466.

[8] Colombo, Luca, Herbert Dawid, and Kordian Kabus (2012): "When do thick venture capital markets foster innovation? An evolutionary analysis", Journal of Evolutionary Economics, Vol. 22, pp. 79-108.

[9] Czarnitzki, Dirk and Hanna Hottenrott (2011): "R\&D investment and financing constraints of small and medium-sized firms", Small Business Economics, Vol. 36, pp. 65-83.

[10] Dosi, Giovanni, Giorgio Fagiolo, Mauro Napoletano, Andrea Roventini, and Tania Treibich (2011): Economic Policies with Endogenous Innovation and Keynesian Demand Management, available under http://www.nccert.biz/badania/ konferencje/2011/dsge/files/Economic.pdf, accessed Jan. 29, 2014.

[11] Fagerberg, Jan, and Bart Verspagen (2002): "Technology-gaps, innovation-diffusion and transformation: an evolutionary interpretation", Research Policy, Vol 31, pp. 12911304. 
[12] Freel, Mark S (2007): “Are Small Investors Credit Rationed?", Small Business Economics, Vol. 28, pp. 23-35.

[13] Gilbert, Richard (2006): "Looking for Mr. Schumpeter: Where Are We in the Competition-Innovation Debate?", in Adam B Jaffe, Josh Lerner and Scott Stern (eds.), Innovation Policy and the Economy, Vol. 6, MIT Press.

[14] Giudici, Giancarlo and Stefano Pateari (2000): "The Provision of Finance to Innovation: A Survey Conducted Among Italian Technology-Based Small Firms", Small Business Economics, vol. 14 (1), pp. 37-53.

[15] Guiso, Luigi (1998): "High-tech firms and credit rationing", Journal of Economic Behavior and Organization, Vol. 35, pp. 39-59.

[16] Hall, Bronwyn $\mathrm{H}$ and Josh Lerner (2009): The Financing of R\&D and Innovation, NBER Working Paper.

[17] Hao, Kenneth $\mathbf{Y}$ and Adam B Jaffe (1993): "Effect of liquidity on firms' R\&D spending", Economics of Innovation and New Technology, Vol. 2 (4), pp. 275-282.

[18] Huang, Haizhou and Changgang Xu (1999): "Institutions, Innovations, and Growth", American Economic Review, Vol. 89 (2), pp. 438-444.

[19] Hyytinen, Ari and Otto Toivanen (2003): "Do financial constraints hold back innovation and growth? Evidence on the role of public policy", ETLA discussion papers, No. 820.

[20] Kremer, Eduard and Wolfgang ten Hoevel (1989): Kredite an Unternehmen: Kreditentscheidung unter dynamischen Aspekten (Corporate Credit: Credit Decision Under Dynamic Aspects), 2nd edition, Deutscher Sparkassenverlag, Stuttgart.

[21] Lee, Jeho and J Richard Harrison (2001): "Innovation and Industry Bifurcation: the Evolution of R\&D Strategy", Industrial and Corporate Change, Vol. 10 (1), pp. 117-149.

[22] Mancusi, Maria L and Andrea Vezzuli (2010): "R\&D, Innovation and Liquidity Constraints", CONCORD 2010 Conference, Sevilla, 3-4 March 2010.

[23] Mohnen, Pierre A, Franz Palm, Sybrand van der Loeff, and A Tiwari (2008): Financial constraints and other obstacles: are they a threat to innovation activity?, CESifo Working Paper, No. 2204.

[24] Nelson, Richard R and Sidney G Winter (1982): An Evolutionary Theory of Economic Change, Belknap, Cambrigde (MA).

[25] Piga, Claudio A and Gianfranco Atzeni (2007): "R\&D Investment, Credit Rationing and Sample Selection", Bulletin of Economic Research, Vol. 59 (2), pp. 149-178. 
[26] Reichling, Peter, Daniela Bietke, and Antje Henne (2003): Praxishandbuch Risikomanagement und Rating (Practical Handbook Risk Management and Rating), 2nd edition (2007), Gabler, Wiesbaden.

[27] Savignac, Frédérique (2008): "Impact of financial constraints on innovation: What can be learned from a direct measure?", Economics of Innovation and New Technology, $17(6), 553-569$.

[28] Sheskin, David J (2011): Handbook of parametric and nonparametric statistical procedures, 5th edition, CRC Press, Boca Raton.

[29] Schumpeter, Joseph A (1939): Business Cycles, McGraw Hill, London.

[30] Schumpeter, Joseph A (1942): Capitalism, Socialism, and Democracy, Reprint 2010, Routledge, London.

[31] Takalo, Tuomas and Tanja Tanayama (2010): "Is there need for R\&D subsidies?". The Journal of Technology Transfer, Vol. 35 (1), pp. 16-41.

[32] Winter, Sidney G (1984): "Schumpeterian Competition in Alternative Technological Regimes", Journal of Economic Behavior \& Organization, Vol. 5, pp. 287-320.

[33] Yildizoglu, Murat (2001): Connecting adaptive behaviour and expectations in models of innovation: The Potential Role of Artificial Neural Networks, Working Paper.

[34] Yildizoglu, Murat (2002): “Competing R\&D Strategies in an Evolutionary Industry Model", Computational Economics, Vol. 19, pp. 51-65. 


\section{Appendix}

\section{Parameters and Variables}

\begin{tabular}{|l||r||r|}
\hline Control Parameters & & \\
\hline \hline interest rate & $i$ & 0.05 \\
average credit supply in unit of capital & $L_{t}^{s}$ & 0.027 \\
bank's weighing parameter for credit offer & $\lambda$ & 0.3 \\
firms' R\&D adjustment policy parameter & $\lambda^{F}$ & 2 \\
\hline
\end{tabular}

\begin{tabular}{|l||r||r|}
\hline Parameters & & \\
\hline \hline Demand & $D$ & 1,000 \\
initial no. of firms & & 10 \\
initial capital & $K_{i t}^{0}$ & 100 \\
initial technology & $A_{i t}^{0}$ & 0.15 \\
initial R\&D spending desire & $\Phi_{i t}^{0}$ & 0.004 \\
minimum R\&D spending desire & $b^{R D}$ & 0.002 \\
innovative R\&D success probability & $a_{i t}^{i n}$ & 0.007 \\
imitative R\&D success probability & $a_{i t}^{i n}$ & 0.02 \\
depreciation rate & $\delta$ & 0.03 \\
production costs & $c$ & 0.16 \\
lower capital barrier for bankruptcy & $c r i t$ & 1 \\
time horizon for looking back & $T$ & 3 \\
markup parameter for investment desire & $\varphi$ & 3 \\
\hline
\end{tabular}

\section{Robustness Check}

In order to check whether the results are robust, a Wilcoxon Signed Rank test is conducted. The Wilcoxon Signed Rank test is performed because it allows for testing samples where a normal distribution cannot be assumed and where the variance is unknown. It is a non parametric test. The following procedure is as described by Sheskin. ${ }^{45}$ Basically, the test is whether the medians of two sample populations (data sets) are likely to be the same at a certain level of significance. If so, the two sample populations can be assumed to be drawn from the same distribution. Some assumptions are essential for the test:

\footnotetext{
${ }^{45}$ See Sheskin 2011, pp. 245 ff.
} 
1. The observed data either constitute a random sample of $N$ independent pairs of items.

2. The observed data are measured at a higher level than the ordinal scale.

3. The distribution of the population of difference scores between repeated measurements of between matched items of individuals is approximately symmetric.

The Null-hypothesis is that the two populations which the results stem from do not differ in their median $\nu: H_{0}: \nu_{1}=\nu_{2}$ while the alternative is for a two tailed test $H_{\text {alt }}: \nu_{1} \neq \nu_{2}$. that is, the median of population 2 is either below or above the median of population 1 . The results are checked for a significance level of $95 \%$, that is $\alpha=0.05$. Each pair of data is compared and the difference taken $W_{i}=x_{1 i}-x_{2 i}$ for all $i=1, \ldots, N$. Zero differences $W_{i}=0$ are discarded and the sample size left is $n$. Since a two tailed test is conducted, the test statistics is the minimum of the sums of negative and positive differences in the pairs of the samples,

$$
W:=\operatorname{Min}\left[\left|W_{-}\right|, W_{+}\right]
$$

If the sample size is sufficiently large, $W$ can be assumed to be normally distributed. Then, a $z$-value can be computed using the number of nonzero differences $n$. This can also be done for the continuation of data in order to better compare the continuous normal distribution with discrete data in the form

$$
z=\frac{\left|W-\frac{n(n+1)}{4}\right|-0.5}{\sqrt{\frac{n(n+1)(2 n+1)}{24}}} .
$$

In this test, the $H_{0}$ hypothesis can be rejected if $|z| \geq z^{\text {crit }}$ where $z^{\text {crit }}$ is the critical value at a significance level chosen according to a table. For a significance level $\alpha=0.05$ the critical value is $z^{\text {crit }}=1.645$.

The intervals that the parameters for the test are chosen from are: The following tables depict

$$
\begin{aligned}
\hline \delta & \in[0.025,0.035] \\
c & \in[0.15,0.17] \\
a^{i m} & \in[0.018,0.022] \\
a^{i n} & \in[0.0065,0.0075] \\
b^{R D} & \in[0.0015,0.0025] \\
\varphi & \in[2.5,3.5]
\end{aligned}
$$

Table 1: Parameter space for the robustness check

the result of the Wilcoxon Signed Rank test for 100 random samples of above parameter space. If the Null Hypothesis cannot be rejected, " $n s$ " is depicted. If it can be rejected, then the direction of difference between sample medians is shown. 


\begin{tabular}{l|l||c|c|c}
$\lambda=0$ vs. $\lambda=0.5$ \\
\hline firm rule & credit supply & $A^{\text {Max }}$ & Herfindahl & Output \\
\hline$\lambda^{F}=0$ & Ls $=0.02$ & $>$ & $>$ & $>$ \\
& $L s=0.03$ & $>$ & $>$ & $>$ \\
& $L s=0.05$ & $>$ & $n s$ & $n s$ \\
\hline$\lambda^{F}=1$ & $L s=0.02$ & $>$ & $>$ & $>$ \\
& $L s=0.03$ & $n s$ & $>$ & $n s$ \\
& $L s=0.05$ & $n s$ & $>$ & $n s$ \\
\hline$\lambda^{F}=2$ & $L s=0.02$ & $<$ & $>$ & $>$ \\
& $L s=0.03$ & $n s$ & $>$ & $n s$ \\
& $L s=0.05$ & $n s$ & $>$ & $n s$ \\
\hline
\end{tabular}

\begin{tabular}{l|l||c|c|c}
\multicolumn{5}{l}{$\lambda=0.5$ vs. $\lambda=1$} \\
\hline firm rule & credit supply & $A^{\text {Max }}$ & Herfindahl & Output \\
\hline$\lambda^{F}=0$ & Ls $=0.02$ & $<$ & $n s$ & $>$ \\
& Ls $=0.03$ & $n s$ & $n s$ & $n s$ \\
& $L s=0.05$ & $n s$ & $n s$ & $n s$ \\
\hline$\lambda^{F}=1$ & $L s=0.02$ & $>$ & $>$ & $>$ \\
& $L s=0.03$ & $>$ & $n s$ & $>$ \\
& $L s=0.05$ & $n s$ & $n s$ & $n s$ \\
\hline$\lambda^{F}=2$ & $L s=0.02$ & $>$ & $>$ & $n s$ \\
& $L s=0.03$ & $>$ & $>$ & $>$ \\
& $L s=0.05$ & $n s$ & $<$ & $n s$ \\
\hline
\end{tabular}

\begin{tabular}{l|l||c|c|c}
\multicolumn{5}{l}{$\lambda=0$ vs. $\lambda=1$} \\
\hline firm rule & credit supply & $A^{\text {Max }}$ & Herfindahl & Output \\
\hline$\lambda^{F}=0$ & Ls $=0.02$ & $>$ & $>$ & $>$ \\
& Ls $=0.03$ & $>$ & $>$ & $>$ \\
& $L s=0.05$ & $n s$ & $>$ & $n s$ \\
\hline$\lambda^{F}=1$ & $L s=0.02$ & $>$ & $>$ & $>$ \\
& $L s=0.03$ & $>$ & $>$ & $>$ \\
& $L s=0.05$ & $n s$ & $n s$ & $n s$ \\
\hline$\lambda^{F}=2$ & $L s=0$ & $>$ & $>$ & $>$ \\
& $L s=0.03$ & $>$ & $>$ & $>$ \\
& $L s=0.05$ & $n s$ & $n s$ & $n s$ \\
\hline
\end{tabular}

Table 2: Results of the Wilcoxon-Signed-Rank Test 